\title{
Pengaruh lon Kadmium(II) dan Nikel(II) pada Ekstraksi lon Tembaga(II) dengan Ekstraktan 4-Benzoil -1-Fenil-3-Metil- 2- Pirazolin-5-On Menggunakan Emulsi Membran Cair
}

\author{
Baharuddin Hamzah $^{\left.1^{*}\right)}$, Noor Jalaluddin²), Abdul Wahid Wahab ${ }^{2)}$, dan Ambo Upe ${ }^{2)}$ \\ 1)Fakultas Keguruan dan Ilmu Pendidikan, Universitas Tadulako, Palu 94118 \\ 2)Fakultas Matematika dan Ilmu Pengetahuan Alam, Universitas Hasanuddin, Makassar 90245
}

Diterima 20-05-2009 Disetujui 23-08-2010

\begin{abstract}
The effects of cadmium(II) and nickel(II) ions to copper(II) extraction using liquid membrane emulsion with 4benzoyl-3-methyl-1-phenyl-2-pyrazolin-5-on (HPMBP) as an extractant was studied. The optimum condition for copper(II) extraction were as follows: emulsification rate $=2000 \mathrm{rpm}$, emulsification time $=10$ minutes, extraction rate $=300 \mathrm{rpm}$, extraction time $=15$ minutes, concentration of mixed surfactant (span $80+\mathrm{span} 20$ ) $=3 \%$, volume ratio of membrane phase and internal phase $=1: 1$, concentration of $\mathrm{HPMBP}=0.020 \mathrm{M}$, concentration of $\mathrm{HCl}=1 \mathrm{M}$, volume ratio of emulsion and external phase $=1: 7$. The result showed that the extraction of copper(II) by liquid membrane emulsion with HPMBP as an extractant was selective to cadmium(II) and nickel(II) ions, relatively. The result also showed that in the extraction of $500 \mathrm{mg} / \mathrm{l} \mathrm{copper(II),} \mathrm{the} \mathrm{presence} \mathrm{of} 500 \mathrm{mg} / \mathrm{l}$ of nickel(II) was decreasing the percentage of copper(II) extraction to be 83.73 . While, the presence of $500 \mathrm{mg} / \mathrm{l}$ of cadmium(II) does not influence the percentage extraction of copper(II), relatively.
\end{abstract}

Keywords: HPMBP, liquid membrane emulsion, copper(II)

\section{PENDAHULUAN}

Keberadaan ion logam berat dalam beberapa limbah cair industri misalnya industri pelapisan logam, industri baterai, industri cat, industri keramik dan industri penyamakan kulit, merupakan suatu contoh yang kompleks dari pencemaran. Hal itu disebabkan karena sifat racun logam berat yang mempengaruhi makhluk hidup terutama terhadap manusia yang dapat menimbulkan penyakit kanker paru-paru, hepatitis, sirosis, parkinson, anemia, gastroentritis, diare, ensefalopati, dermatitis, edema paru, gangguan pernafasan, gangguan fungsi ginjal, dll. Oleh karena itu ekstraksi logam berat seperti timbal, kadmium, krom, tembaga, nikel, perak, raksa dan lain-lain dalam pengolahan limbah cair merupakan hal yang penting untuk diperhatikan.

Teknik pengolahan limbah cair secara konvensional untuk memperoleh kembali logam-logam seperti pengendapan dan penyaringan selain menghasilkan limbah padat juga pereaksi yang digunakan secara berlebihan akan menjadi pencemar yang baru. Ekstraksi cair-cair untuk memperoleh kembali logam-logam adalah alternatif lain,

\footnotetext{
*Telp: +6281342267483

Email: hamzahhb@yahoo.com
}

namun kurang ekonomis dan kurang efisien karena menggunakan beberapa tahap ekstraksi dan ekstraksi balik. Teknik pemisahan yang masih berkembang hingga kini adalah teknik yang berdasarkan membran cair. Teknik ini memberikan jangkauan aplikasi yang luas dan potensial karena mudah dalam pengoperasiannya, biaya operasional yang relatif lebih murah dan efisien dengan keselektifan yang tinggi. (Li, 1971; Lee et al., 1978; Chaudry \& Malik, 1997; Gyves \& Miguel, 1999; Chakravarti et al., 2000; Kumaresan et al., 2003; Gawronski \& Religa, 2007). Salah satu jenis teknik pemisahan berdasarkan membran cair adalah teknik emulsi membran cair. Teknik ini telah digunakan untuk memisahkan fenol dari air buangan industri (Cahn \& Li, 1976), ekstraksi berbagai jenis logam (Boyadzhiev \& Lazarova, 1987; Raghuraman et al., 1993; Raghuraman et al., 1994; Uddin \& Kathiresan, 2000; Yang et al., 2005; Othman et al., 2006; Saravanan et al., 2006; Valenzuela et al., 2009), dan ekstraksi asam amino (Bhuvaneswari et al., 2003; Venkatesan et al., 2004).

Dalam penelitian ini mekanisme transport ion logam didasarkan pada reaksi yang terjadi antara ion logam misalnya $\mathrm{Cu}^{2+}$ dalam fasa eksternal dengan ekstraktan HPMBP sebagai zat pembawa kation yang 
dilarutkan dalam fasa membran (kerosene). Pada Gambar 1 terlihat bahwa dengan adanya pengadukan menyebabkan terjadinya reaksi pada permukaan luar membran antara ion $\mathrm{Cu}^{2+}$ dengan HPMBP membentuk kompleks $\mathrm{Cu}(\mathrm{PMBP})_{2}$ yang larut baik dalam membran. Kemudian kompleks ini berdifusi di dalam membran cair menuju fasa internal. Oleh karena adanya zat pembebas (asam kuat) di dalam fasa internal, maka ion $\mathrm{Cu}^{2+}$ akan dilepaskan dari senyawa kompleksnya pada permukaan dalam membran. Selanjutnya zat pembawa HPMBP yang telah melepaskan ion $\mathrm{Cu}^{2+}$ tersebut akan berdifusi kembali ke permukaan luar membran untuk membentuk kompleks yang baru dengan ion $\mathrm{Cu}^{2+}$ lainnya.

Pada ekstraksi logam dengan teknik membran cair selalu dibutuhkan zat pembawa (ekstraktan). Ekstraktan yang sering digunakan antara lain benzoil aseton (Noviandri, 1992), trioktil metil amonium klorida (Park et al., 2001), tri-n-oktilamin atau TOA (Kozlowski et al., 2002), asam di-2-etilheksil-fosfat atau HDEHP (Bourenane et al., 2003; Basualto et al., 2006; Sabry et al., 2007), amina tersier (Kozlowski \& Walkowiak, 2005), ketokonazol (Farhadi \& Shamsipur, 2005), dll. Walaupun ekstraktan-ekstraktan tersebut telah digunakan secara luas dalam ekstraksi ion logam menggunakan teknik emulsi membran cair, namun pada umumnya konsentrasi zat pembawa yang digunakan cukup besar hingga 20\%, (Chiha et al., 2006), sehingga kurang efisien dan tidak ekonomis. Oleh karena itu dalam penelitian ini digunakan ekstraktan yang penggunaannya lebih sedikit, lebih efisien dan dapat memberikan persen ekstraksi yang lebih tinggi yaitu HPMBP (Jia et al., 1988; Ivanova, 1987; Roy \& Nag, 1978; Saleh et.al., 1990; Amrit \& Patel, 1993; Hamzah, 2001). Di dalam limbah cair industri misalnya industri pelapisan logam, ion tembaga(II) sering berada bersama ion-ion logam lain seperti kadmium(II), kobal(II), nikel(II), $\operatorname{krom}(\mathrm{VI})$, seng dlI. Ekstraksi ion tembaga(II) menggunakan emulsi membran cair telah banyak dilakukan (Valenzuela et al., 2005; Sengupta et al., 2006; Mitiche et al., 2008), namun pada umumnya tidak

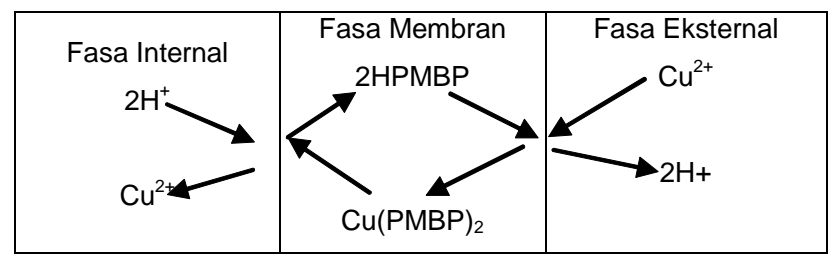

Gambar 1. Mekanisme transport ion tembaga(II) dalam emulsi membran cair mempelajari pengaruh keberadaan ion-ion lain dalam larutan terhadap persen ekstraksi ion tembaga(II). Oleh karena itu, dalam tulisan ini akan dipaparkan pengaruh ion-ion kadmium(II) dan nikel(II) terhadap persen ekstraksi ion tembaga(II).

\section{BAHAN DAN METODE}

Bahan-bahan yang digunakan adalah: 1-fenil-3metil-2-pirazolin-5-on, benzoil klorida, tembaga(II) sulfat, kadmium(II) nitrat, nikel(II) sulfat, asam nitrat, asam klorida, natrium hidroksida, kalsium hidroksida, span80, span-20, kerosene, 1,4-dioksan, n-heksan dan air suling.

Peralatan utama yang digunakan adalah sintesis set (reflux, labu leher tiga, thermometer, hot plate, pompa vakum), spektrofotometer (FTIR, H-NMR, SSA), peralatan gelas yang biasa digunakan dalam laboratorium, emulsifier 0-4000 rpm.

Sintesis dan penentuan struktur HPMBP. Sintesis dilakukan dengan jalan melarutkan sejumlah 1-fenil-3-metil-2-pirazolin-5-on dalam $80 \mathrm{ml}$ 1,4-dioksan dalam labu leher tiga yang dilengkapi dengan pendingin refluks, pengaduk magnetik dan corong pisah, pada temperatur $75^{\circ} \mathrm{C}$. Setelah larut, secara perlahan-lahan dan sedikit demi sedikit ditambahkan sejumlah kalsium hidroksida sampai homogen. Sambil diaduk, melalui corong pisah ditambahkan benzoil klorida sedikit demi sedikit. Kemudian temperatur pemanasan dinaikkan sampai $100-120^{\circ} \mathrm{C}$ dan direfluks selama 30 menit. Setelah refluks selesai, dalam keadaan panas campuran dimasukkan ke dalam labu dasar rata yang berisi larutan $\mathrm{HCl} 2 \mathrm{M}$ sambil diaduk dengan pengaduk magnetik selama 45 menit. Kristal kotor yang terbentuk disaring dengan penyaring Buchner dan dicuci dengan sedikit air dan 1,4-dioksan serta dikeringkan, timbang untuk menghitung rendemennya. Uji struktur menggunakan spektrofotometer FTIR dan H-NMR.

Pembuatan emulsi membran cair. Sebagai fasa internal digunakan larutan asam klorida $1 \mathrm{M}$ dan sebagai fasa membran digunakan larutan HPMBP dalam kerosene yang mengandung surfaktan campuran Span-80 dan Span-20. Emulsi dibuat dengan mencampurkan kedua larutan ini dalam suatu wadah pembuat emulsi dan diaduk dengan kecepatan 2000 rpm selama 10 menit.

Pengaruh ion kadmium(II) dan nikel(II) terhadap persen ekstraksi ion tembaga(II). Percobaan ini dimaksudkan untuk mengetahui 
pengaruh ion kadmium(II) dan nikel(II) terhadap persen ekstraksi ion tembaga(II) dan selektivitas ekstraksi ion tembaga(II) terhadap kedua ion tersebut. Untuk itu dibuat larutan-larutan yang mengandung $500 \mathrm{mg} / \mathrm{l}$ ion tembaga(II) dan ion kadmium(II) atau ion nikel(II) dengan konsentrasi bervariasi 0-500 mg/l. Kemudian dilakukan ekstraksi dengan menggunakan kondisi optimum ekstraksi ion tembaga(II) sebagai berikut: laju emulsifikasi=2000 rpm, waktu emulsifikasi=10 menit, laju ekstraksi=300 rpm, lama ekstraksi=15 menit, konsentrasi surfaktan campuran (span-80 + span$20)=3 \%$, perbandingan volume fasa membran dan fasa internal $=1: 1$, konsentrasi $\mathrm{HPMBP}=0,020 \mathrm{M}$, konsentrasi $\mathrm{HCl}=1 \mathrm{M}, \mathrm{pH}$ fasa eksternal=3,26, perbandingan volume emulsi dan fasa eksternal=1:7. Setelah ekstraksi, kadar masing-masing ion logam ditentukan dengan spektrofotometer serapan atom pada panjang gelombang $324,7 \mathrm{~nm}(\mathrm{Cu}), 228,9 \mathrm{~nm}(\mathrm{Cd})$ dan 232,0 nm (Ni).

\section{HASIL DAN PEMBAHASA}

Sintesis dan penentuan struktur HPMBP. Reaksi pembentukan HPMBP dimulai dengan melarutkan senyawa 1-fenil-3-metil-5-pirazolon dalam 1,4-dioksan pada suhu $75^{\circ} \mathrm{C}$. Selanjutnya ditambahkan suspensi kalsium hidroksida dalam air sedikit demi sedikit, yang berfungsi sebagai katalis diikuti dengan penambahan benzoil klorida tetes demi tetes. Reaksi pembentukan HPMBP merupakan reaksi asilasi yang menggunakan kondisi reaksi Schotten-Baumann yang diikuti dengan penataan ulang Fries dan tautomeri seperti reaksi pada Gambar 2. Istilah kondisi reaksi ini sering digunakan untuk mengindikasi penggunaan sistem pelarut dua fasa. Larutan basa dalam fasa air juga berfungsi untuk menetralisir asam yang terbentuk dalam reaksi, sedangkan pereaksi dan produknya berada dalam fasa organik. (Kociensky, 2007).

Hasil sintesis berupa kristal kuning cerah dengan titik leleh $87-89^{\circ} \mathrm{C}$ dan rendemen $72,04 \%$. Berdasarkan spektrum infra merah pada Gambar 3, rentangan - $\mathrm{OH}$ diperlihatkan dengan adanya puncak melebar pada bilangan gelombang $3101-2520 \mathrm{~cm}^{-1}$ sedangkan adanya puncak pada $1641 \mathrm{~cm}^{-1}$ menunjukkan adanya rentangan $\mathrm{C}=\mathrm{O}, \mathrm{C}=\mathrm{C}$ (aromatik/non aromatik) atau $\mathrm{C}=\mathrm{N}$. Puncak pada bilangan gelombang $1352 \mathrm{~cm}^{-1}$ dan 1568-1450 $\mathrm{cm}^{-1}$ berturut-turut menunjukkan adanya bengkokan $-\mathrm{CH}_{3}$ dan cincin aromatik, sedangkan adanya rentangan $\mathrm{C}-\mathrm{H}$ aromatik diperlihatkan dengan adanya puncak pada $3059 \mathrm{~cm}^{-1}$. Adanya puncak-puncak tersebut menunjang struktur HPMBP.

Dari hasil spektrum H-NMR dengan pergeseran kimia 2-13 ppm pada Gambar 4 dan pergeseran kimia 7-8 ppm pada Gambar 5, terlihat adanya puncak singlet pada pergeseran kimia 2,00 ppm yang spesifik untuk gugus metil $\left(-\mathrm{CH}_{3}\right)$ dengan 3 buah proton yang sesuai dengan ketinggian integral spektrumnya $(2,914)$. Puncak singlet pada pergeseran kimia sekitar 13,00 ppm juga tampak mengidentifikasi adanya gugus $-\mathrm{OH}$ dari karboksil dengan 1 buah proton, sesuai dengan ketinggian integral spektrumnya $(0,557)$. Puncak triplet pada pergeseran kimia 7,30 ppm (integrasi $=0,961$ ) dan $7,58 \mathrm{ppm}$ (integrasi $=0,987$ ) adalah untuk proton para<smiles>CCCCCN1N=C(C)CC1=O</smiles>

1-fenil-3-metil-5-pirazolon<smiles>O=C(Cl)c1ccccc1</smiles>

benzoil klorida<smiles>CCCCCN1N=C(C)CC1OC(=O)c1ccccc1</smiles>

Penataan ulang Fries<smiles>CCC(C)C(O)C1C(=O)N(S)N=C1C</smiles>

1-fenil-3-metil-4-benzoil-5-pirazolon

Gambar 2. Reaksi sintesis HPMBP 


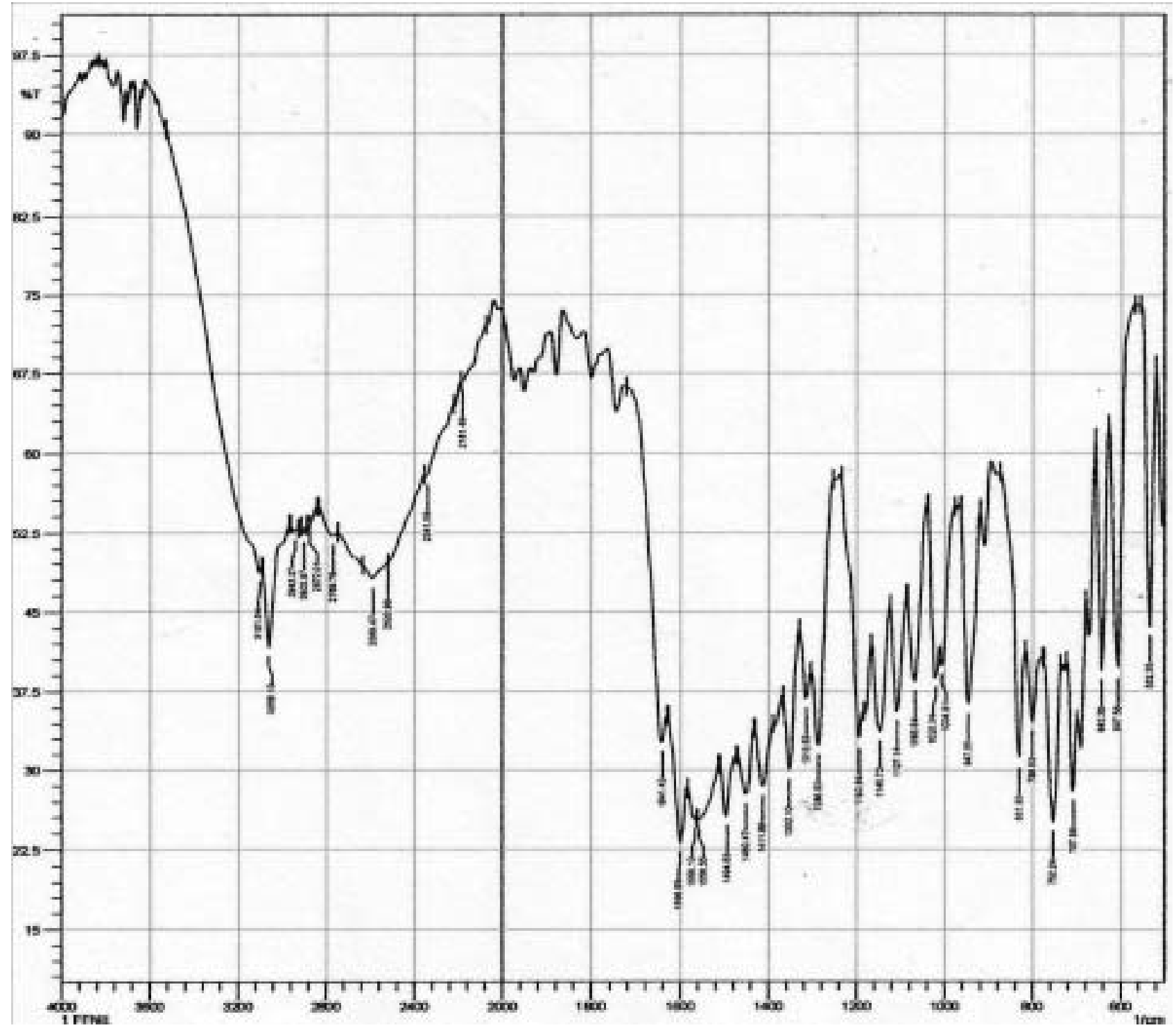

Gambar 3. Spektrum Inframerah HPMBP

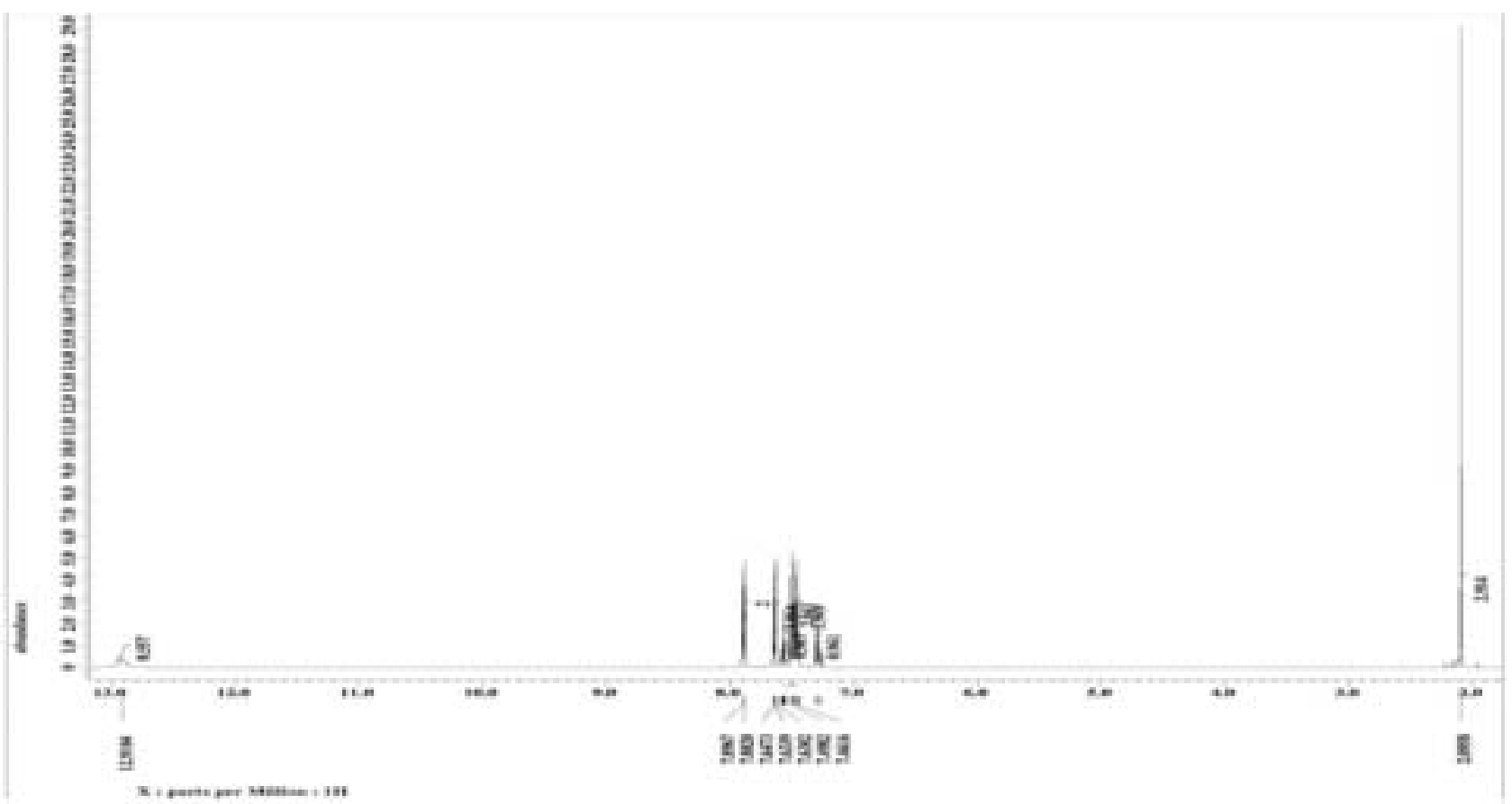


sedangkan puncak triplet pada pergeseran kimia 7,46 ppm (integrasi $=1,949$ ) dan 7,64 ppm (integrasi $=1,964$ ) adalah untuk proton orto. Puncak proton meta diperlihatkan dengan adanya puncak doblet pada pergeseran kimia sekitar 7,50 ppm (integrasi $=2,041$ ) dan 7,89 ppm (integrasi=2,000). Dengan demikian jumlah proton keseluruhan yang dimiliki HPMBP berdasarkan analisis struktur menggunakan spektrofotometer H-NMR adalah 14 dan hal ini sesuai dengan struktur HPMBP yang diharapkan.

Pengaruh ion kadmium(II) terhadap persen ekstraksi ion tembaga(II) dan persen ekstraksi ion kadmium(II). Percobaan ini bertujuan untuk mempelajari pengaruh ion kadmium(II) terhadap persen ekstraksi ion tembaga(II) yang dilakukan dengan jalan mengekstraksi ion tembaga(II) $500 \mathrm{mg} / \mathrm{l}$ dalam campurannya dengan ion kadmium(II) 0-500 mg/l. Berdasarkan hasil percobaan diperoleh kurva hubungan konsentrasi ion kadmium(II) terhadap persen ekstraksi ion tembaga(II) dan juga terhadap persen ekstraksi ion kadmium(II) sesuai pada Gambar 6 . Kurva pada Gambar 6 menunjukkan bahwa dengan penambahan konsentrasi ion kadmium(II) $0-500 \mathrm{mg} / \mathrm{l}$ relatif tidak mempengaruhi persen ekstraksi ion tembaga(II) karena persen ekstraksi ion tembaga(II) relatif konstan (98,08\%-97,33\%).

Gambar 5. Spektrum H-NMR HPMBP 7-8 ppm

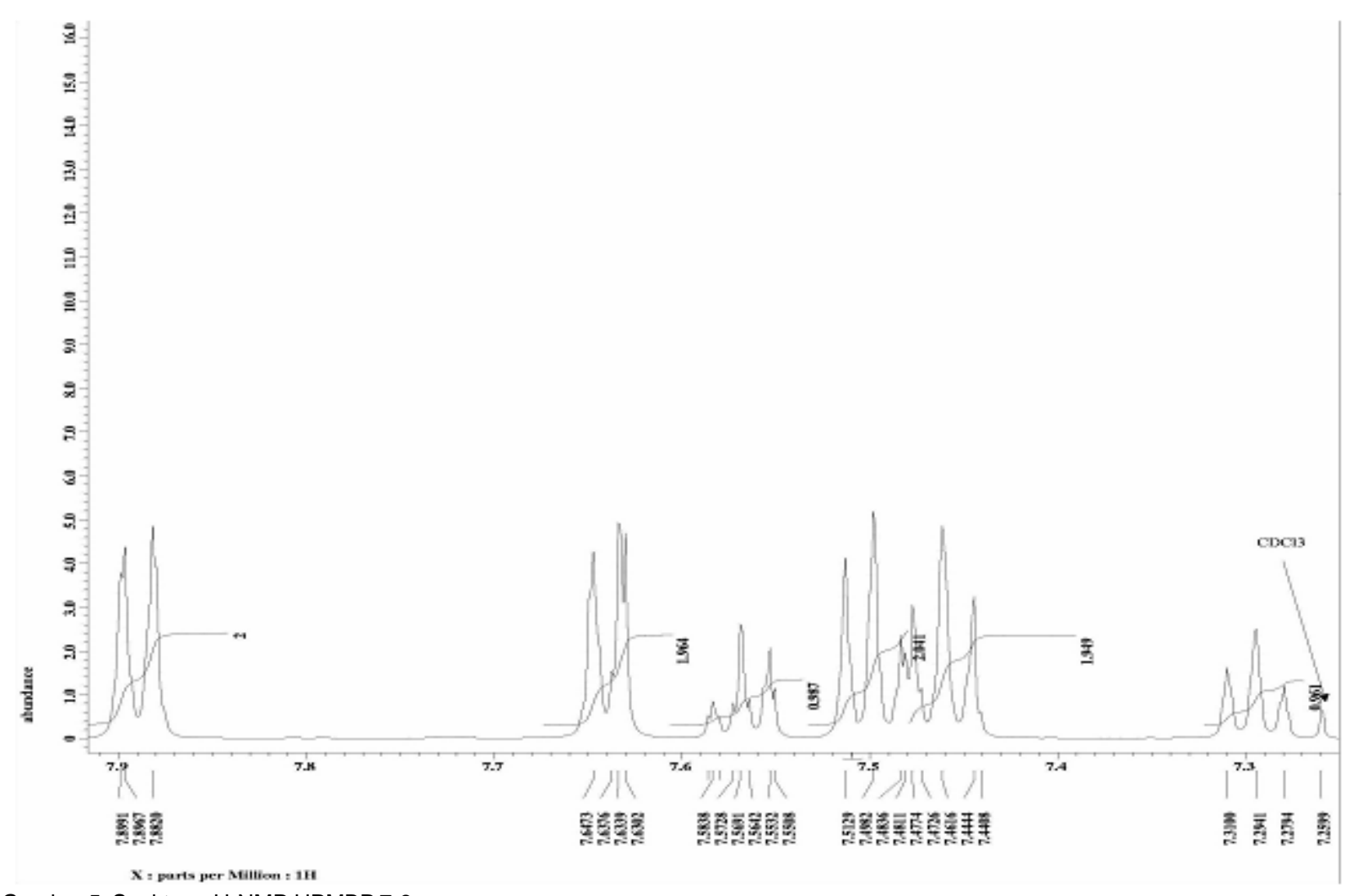

Selektivitas ekstraksi ion tembaga(II) terhadap ion kadmium(II) ditentukan dengan mengukur konsentrasi ion kadmium(II) dalam fasa eksternal sesudah ekstraksi. Kurva pada Gambar 6 juga menunjukkan bahwa ekstraksi ion tembaga(II) dengan menggunakan kondisi optimum ekstraksi ion tembaga(II) ternyata selektif terhadap ion kadmium(II). Hal ini ditunjukkan oleh relatif tidak adanya ion kadmium(II) yang ikut terekstraksi. Pemisahan kedua ion logam ini dipengaruhi oleh banyak faktor, diantaranya adalah keefektifan pembentukan kompleks pada permukaan luar fasa membran. Keefektifan pembentukan kompleks $\mathrm{Cu}(\mathrm{PMBP})_{2}$ lebih besar dari pada pembentukan

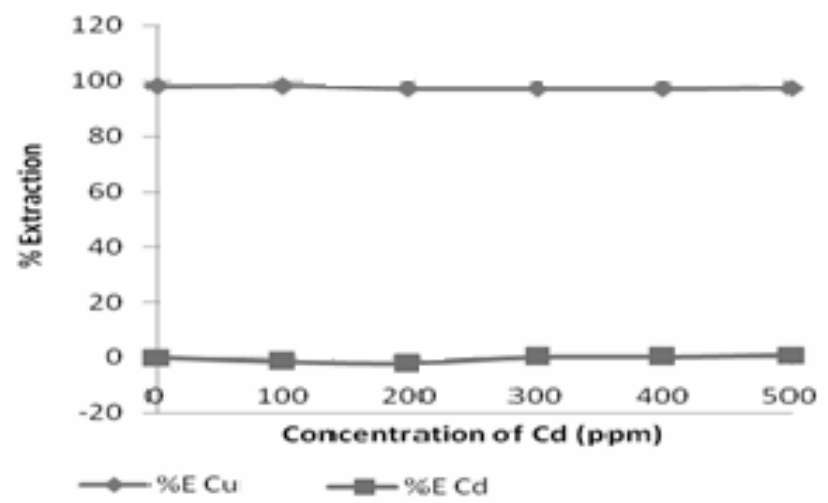

Gambar 6. Kurva hubungan konsentrasi ion kadmium(II) terhadap persen ekstraksi ion tembaga(II) dan persen ekstraksi ion kadmium(II) 
kompleks $\mathrm{Cd}(\mathrm{PMBP})_{2}$ yang dapat diuraikan sebagai berikut. Pertama, ion tembaga(II) mempunyai jari-jari ion yang lebih kecil dari ion kadmium(II). Menurut teori medan kristal, pada pembentukan kompleks makin kecil ion logam maka makin besar medan listriknya, sehingga makin stabil kompleks yang dibentuknya. Dengan demikian kompleks $\mathrm{Cu}(\mathrm{PMBP})_{2}$ lebih stabil dari pada kompleks $\mathrm{Cd}(\mathrm{PMBP})_{2}$. Kedua, HPMBP merupakan ligan dengan atom $\mathrm{O}$ sebagai donor pasangan elektron, sehingga digolongkan sebagai basa Lewis keras. Menurut prinsip HSAB (Hard and Soft Acids and Bases), asam Lewis keras (kation logam keras) membentuk kompleks yang lebih stabil dengan basa Lewis keras (ligan keras) sedangkan asam Lewis lunak lebih menyukai basa Lewis lunak. Berdasarkan penggolongannya, ion kadmium(II) termasuk asam Lewis lunak sedangkan ion tembaga(II) termasuk golongan antara (intermediate). Akibatnya, kestabilan kompleks $\mathrm{Cu}(\mathrm{PMBP})_{2}$ akan lebih besar dari pada kompleks $\mathrm{Cd}(\mathrm{PMBP})_{2}$

Pengaruh ion nikel(II) terhadap persen ekstraksi ion tembaga(II) dan persen ekstraksi ion nikel(II). Percobaan ini bertujuan untuk mempelajari pengaruh ion nikel(II) terhadap persen ekstraksi ion tembaga(II) yang dilakukan dengan jalan mengekstraksi ion tembaga(II) 500 mg/l dalam campurannya dengan ion nikel(II) 0-500 mg/l. Berdasarkan hasil percobaan diperoleh kurva hubungan konsentrasi ion nikel(II) terhadap persen ekstraksi ion tembaga(II) dan juga terhadap persen ekstraksi ion nikel(II) sesuai pada Gambar 7.

Kurva pada Gambar 7 menunjukkan bahwa dengan penambahan ion nikel(II) 0-100 $\mathrm{mg} / \mathrm{l}$ relatif tidak mempengaruhi persen ekstraksi ion tembaga(II) karena persen ekstraksi ion tembaga(II) relatif konstan

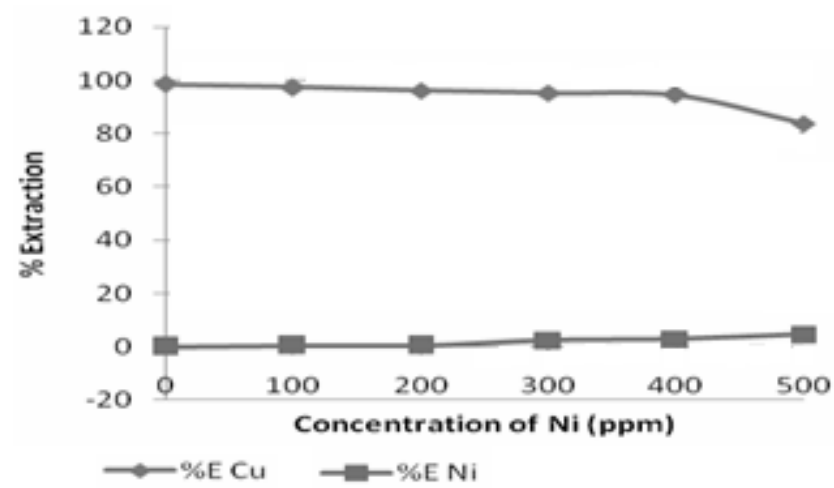

Gambar 7. Kurva hubungan konsentrasi ion nikel(II) terhadap persen ekstraksi ion tembaga(II) dan persen ekstraksi ion nikel(II)
(98,48\%-97,33\%). Namun dengan bertambahnya ion nikel(II) hingga $500 \mathrm{mg} / \mathrm{l}$, persen ekstraksi ion tembaga(II) menurun sampai $83,73 \%$.

Selektivitas ekstraksi ion tembaga(II) terhadap ion nikel(II) ditentukan dengan mengukur konsentrasi ion nikel(II) dalam fasa eksternal sesudah ekstraksi. Kurva pada Gambar 7 juga menunjukkan bahwa ekstraksi ion tembaga(II) dengan menggunakan kondisi optimum ekstraksi ion tembaga(II) ternyata selektif terhadap ion nikel(II). Hal ini ditunjukkan oleh tidak adanya ion nikel(II) yang ikut terekstraksi. Pemisahan kedua ion logam ini dipengaruhi oleh banyak faktor, diantaranya adalah keefektifan pembentukan kompleks pada permukaan luar fasa membran. Keefektifan pembentukan kompleks $\mathrm{Cu}(\mathrm{PMBP})_{2}$ lebih besar dari pada pembentukan kompleks $\mathrm{Ni}(\mathrm{PMBP})_{2}$, yang dapat diuraikan sebagai berikut. HPMBP merupakan ligan medan lemah (high spin) karena mempunyai banyak pasangan elektron. Hampir semua kompleks nikel(II) dengan ligan medan kuat (low spin) berbentuk planar segi empat karena energi stabilisasi medan kristalnya besar sedangkan dengan ligan medan lemah (high spin) cenderung akan membentuk oktahedral. Oleh karena HPMBP merupakan ligan medan lemah, maka jika membentuk kompleks dengan ion nikel(II) akan membentuk struktur oktahedral. Namun struktur oktahedral ini sulit untuk tercapai karena struktur HPMBP yang tidak memungkinkan membentuk struktur oktahedral. Akibatnya, kestabilan kompleks $\mathrm{Cu}(\mathrm{PMBP})_{2}$ akan lebih besar dari pada kompleks $\mathrm{Ni}(\mathrm{PMBP})_{2}$.

\section{KESIMPULAN}

Ekstraksi ion tembaga(II) dengan HPMBP sebagai ekstraktan menggunakan teknik emulsi membran cair, relatif selektif terhadap ion-ion kadmium(II) dan nikel(II). Pada ekstraksi ion tembaga(II) 500 mg/l, keberadaan ion nikel(II) $500 \mathrm{mg} / \mathrm{l}$ ternyata menurunkan persen ekstraksi ion tembaga(II) hingga $83,73 \%$, sedangkan keberadaan ion kadmium(II) $500 \mathrm{mg} / \mathrm{l}$ relatif tidak menurunkan persen ekstraksi ion tembaga(II).

\section{UCAPAN TERIMA KASIH}

Ucapan terima kasih penulis sampaikan untuk promotor Prof.Dr.H.M. Noor Jalaluddin, kopromotor Prof. Dr.H.Abd. Wahid Wahab, MSc. dan Prof. Dr. H. Ambo Upe, DEA atas segala bimbingan, masukan dan saransaran yang telah diberikan. Tidak lupa ucapan terima kasih juga penulis sampaikan untuk sahabat Drs.H. 
Syarifuddin Liong, M.Si. yang telah banyak membantu dalam pelaksanaan penelitian ini.

\section{DAFTAR PUSTAKA}

Amrit, N. \& Patel, R.P. 1993. Metal Extraction 17: 80-90. Basualto, C., Poblete, M., Marchese, J., Ochoa, A., Acosta, A., Sapag, J. \& Valenzuela, F. 2006. Braz. Chem. Soc, 17(7): 1347-1354.

Bhuvaneswari, S., Begum, K.M.M.S., Sivashanmugam, P. \& Anantharaman, N. 2003. Journal of Sci. and Ind. Res, 62: 329-333

Bourenane, S., Samar,M.E.H. \& Abbaci, A. 2003. Acta Chim.Slov 50: 663-675.

Boyadzhiev, L. \& Lazarova, Z. 1987. Chem. Eng. Sci, 42(5): $1131-1135$

Cahn, R.P. \& Li, N.N. 1976. New Development in Separation Methods. Marcel Dekker Inc. New York, 13-27.

Chakravarti, A.K., Chowdhury, S.B. \& Mukherjee, D.C. 2000. Colloids and Surfaces, A Physiochemical and Engineering Aspects, 166:1-3, 7-25.

Chaudry, M.A. \& Malik, S.A.M.T. 1997. Waste Management 17(4): 211-218.

Chiha, M., Samar, M.H. \& Hamdaoni,O. 2006. Desalination 194: $69-80$.

Farhadi, K. \& Shamsipur, M. 2005. Analytical Science. 21 501-505.

Gawronski, R. \& Religa, P. 2007. Journal of Membrane Science, 289(1-2): 187-190.

Gyves, J.de. \& Miguel, E.R., San, de. 1999. Ind. Engg. Chem. Res, 38(6): 2182-2202.

Hamzah, B. 2001.Determination of The Extraction Constant in Cadmium Extraction with HPMBP. Prosiding Seminar Nasional Kimia 2001. Palu, 2-5 Mei 2001.

Ivanova, E. 1987. Anal.Chem. 288: 62.

Jia, Jun-Mao, Fu, L. \& Yude, C. 1988. J.RadioNucl.Chem. 131: 54-63.

Kozlowski, C., Apostoluk, W., Walkowiak, W. \& Kita, A. 2002. Physiochemical Problems of Mineral Processing 36: 115122.

Kozlowski, C. \& Walkowiak, W. 2005. Journal of membrane science, 266(1-2): 143-150.
Kumaresan, T., Begum, K.M.M.S., Sivashanmugam, P., Anantharaman, N. \& Sundaram, S. 2003. Chem. Engg. J. 95: 199-204.

Lee, K.H., Evans, D.F. \& Cussler, E.L. 1978. AlChE J, 24(5): 860-868.

Li, N.N. 1971. Ind. Eng. Chem. Process Res. Dev, 10: 215-221.

Mitiche, L., Tingry, S., Seta, P. \& Sohmoune, A. 2008. Journal of Membrane Science, 25(2): 605-611.

Noviandri, I. 1992. Ekstraksi ion tembaga(II) menggunakan teknik emulsi membran cair. Tesis Pasca Sajana. Bandung: ITB.

Othman, N., Mat, H. \& Goto, M. 2006. Journal of membrane science, 282(1-2): 171-177.

Park,W., Kim,G.W., Kim,S.S. \& Sohn, I.J. 2001. Sep.Sci.Tech, 36(10): 2309-2326.

Raghuraman, B., Tirmizi, N. \& Wiencek, J. 1993. AlChE. J. 39: $39-46$.

Raghuraman, B., Tirmizi, N. \& Wiencek, J. 1994. Environ. Sci. Technol, 28: 1090-1102.

Roy, A. \& Nag, K. 1978. J.Inorganic Nucl.Chem, 40: 331-334.

Sabry, R., Hafez, A., Khedr, M. \& Hassanin, A.E. 2007. Desalination, 212(1-3): 165-175.

Saleh, M.I., Ahmad, M. \& Darus, H. 1990. Talanta, (37): 757759.

Saravanan, S., Begum, K.M.M.S. \& Anantharaman, N. 2006. Journal of the University of Chemical Technology and Metallurgy, 41(3): 333-342.

Sengupta, B., Sengupta, R. \& Subrahmanyam, N. 2006. Hydrometallurgy, 81(1): 67-73.

Uddin, M.S. \& Kathiresan, M. 2000. Sep. Purification Tech, 19: 3-9.

Valenzuela, F., Araneda, C., Vargas, F., Basualto, C. \& Sapag, J. 2009. Chemical Engineering Research and Design, 87(1): 102-108.

Valenzuela, F., Fonseca, C., Basualto, C., Correa, O., Tapia C. \& Sapag, J. 2005. Minerals Engineering, 18: 33-40.

Venkatesan, S., Begum, K.M.M.S., Sivashanmugam, P. \& Anantharaman, N. 2004. Journal of Ind. Chem. Soc, 81: 1-3.

Yang, L., Zhang, Z., Guo, Y., Gao, X. \& Takeuchi, H. 2005. Separation and Purification Technology, 47: 88-94. 